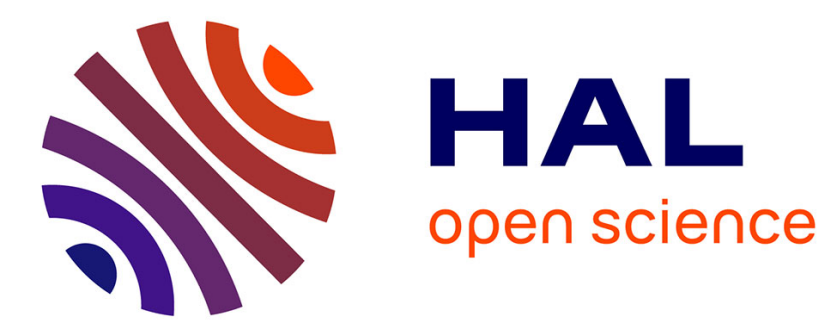

\title{
Comet assay on thawed embryos: An optimized technique to evaluate DNA damage in mouse embryos
}

L. Rolland, B. Courbiere, V. Tassistro, A. Sansoni, T. Orsiere, W. Liu, C. Di

Giorgio, J. Perrin

\section{- To cite this version:}

L. Rolland, B. Courbiere, V. Tassistro, A. Sansoni, T. Orsiere, et al.. Comet assay on thawed embryos: An optimized technique to evaluate DNA damage in mouse embryos. Toxicology in Vitro, 2017, 44, pp.266-272. 10.1016/j.tiv.2017.07.010 . hal-01785372v2

\section{HAL Id: hal-01785372}

https://hal-amu.archives-ouvertes.fr/hal-01785372v2

Submitted on 4 May 2018

HAL is a multi-disciplinary open access archive for the deposit and dissemination of scientific research documents, whether they are published or not. The documents may come from teaching and research institutions in France or abroad, or from public or private research centers.
L'archive ouverte pluridisciplinaire HAL, est destinée au dépôt et à la diffusion de documents scientifiques de niveau recherche, publiés ou non, émanant des établissements d'enseignement et de recherche français ou étrangers, des laboratoires publics ou privés. 


\title{
Comet assay on thawed embryos: An optimized technique to evaluate DNA damage in mouse embryos
}

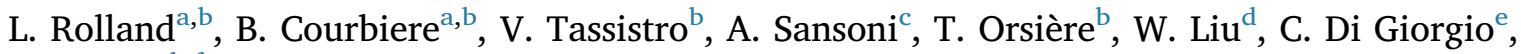 \\ J. Perrin ${ }^{a, b, f, *}$ \\ ${ }^{a}$ Department of Gynecology, Obstetrics and Reproductive Medicine, AP-HM La Conception, Pôle femmes parents enfants, 147 bd Baille, 13005 Marseille, France \\ ${ }^{\mathrm{b}}$ Institut Méditerranéen de Biodiversité et d'Ecologie marine et continentale (IMBE), Aix Marseille Univ, CNRS, IRD, Univ Avignon, Marseille, France \\ ' Centre d'Immunophénomique - CIPHE, PHENOMIN, INSERM US012, CNRS UMS3367, UM2 Aix-Marseille Université Marseille, France \\ d CNRS, Aix Marseille Univ, IRD, CEREGE UM34, UMR 7330, 13545 Aix en Provence, France \\ e Laboratoire de mutagagénèse environnementale, Aix Marseille Univ, Univ Avignon, CNRS, IRD, IMBE, Marseille, France \\ ${ }^{\mathrm{f}}$ CECOS, Laboratory of Reproductive Biology, Department of Gynecology, Obstetric and Reproductive Medicine, Pôle femmes parents enfants, AP-HM La Conception, 147 \\ bd Baille, 13005 Marseille, France
}

\section{A R T I C L E I N F O}

\section{Keywords:}

DNA damage

embryo cryopreservation

Single-Cell Gel Electrophoresis

technical issue

literature review

\begin{abstract}
A B S T R A C T
Our objective was to optimize the CA technique on mammal embryos.

Materials and methods: 1000 frozen 2-cell embryos from B6CBA mice were used. Based on a literature review, and after checking post-thaw embryo viability, the main outcome measures included: 1) comparison of the embryo recovery rate between 2 CA protocols (2 agarose layers and 3 agarose layers); 2) comparison of DNA damage by the $\mathrm{CA}$ on embryos with $(\mathrm{ZP}+)$ and without $(\mathrm{ZP}-)$ zona pellucida; and 3) comparison of DNA damage in embryos exposed to 2 genotoxic agents $\left(\mathrm{H}_{2} \mathrm{O}_{2}\right.$ and simulated sunlight irradiation (SSI)). DNA damage was quantified by the \% tail DNA.

Results: 1) The recovery rate was 3,3\% $(n=5 / 150)$ with the 2 agarose layers protocol and 71,3\% $(n=266 /$ 371) with the 3 agarose layers protocol. 2) DNA damage did not differ statistically significantly between ZP and ZP + embryos $(12.60 \pm 2.53 \%$ Tail DNA vs $11.04 \pm 1.50(p=0.583)$ for the control group and $49.23 \pm 4.16$ vs $41.13 \pm 4.31(p=0.182)$ for the $\mathrm{H}_{2} \mathrm{O}_{2}$ group); 3$) \mathrm{H}_{2} \mathrm{O}_{2}$ and SSI induced a statistically significant increase in DNA damage compared with the control group (41.13 $\pm 4.31 \%$ Tail DNA, $36.33 \pm 3.02$ and $11.04 \pm 1.50(p<0.0001))$.

The CA on mammal embryos was optimized by using thawed embryos, by avoiding ZP removal and by the adjunction of a third agarose layer.
\end{abstract}

\section{Introduction}

The exposure of parents to environmental toxicants, such as polycyclic aromatic hydrocarbons (Einaudi et al., 2014; Perrin et al., 2011), Bisphenol A (Goldstone et al., 2015), solvents (Kolstad et al., 1999), metals (Thompson and Bannigan, 2008; Zhou et al., 2016) or various therapies (Bujan et al., 2014; Esquerré-Lamare et al., 2015; Pecou et al., 2009; Roti Roti et al., 2012) may induce DNA damage in male and female germ cells. DNA damage in parental germ cells can lead to reproductive issues, such as reduced fertilization, impaired early embryonic development, a decreased pregnancy rate and increased miscarriage rate (Simon et al., 2014; Zhao et al., 2014). The transmission of paternal germ cell DNA damage to preimplantation embryos has been demonstrated in humans (Zenzes et al., 1999), although DNA repair occurs in the zygote (Ménézo et al., 2010). This observation raises the question of evaluating DNA damage in preimplantation embryos because, currently, no genotoxicity test on the embryo has been validated.

The comet assay is a simple and rapid test for evaluating DNA damage in eukaryotic cells (Speit et al., 2009). It allows for the visualization of denatured DNA fragments after ex-nucleus migration by electrophoresis. After staining, the obtained shape mimics a "comet" with the head containing intact DNA and the remaining parts of the chromosome and the tail containing relaxed DNA loops or broken DNA fragments (Horváthová et al., 2004). This test is validated by toxicological regulatory agencies for the assessment of DNA damage in somatic cells (OECD, 2014). The comet assay is also used by researchers

\footnotetext{
* Corresponding author at: IMBE, Faculty of Medicine, 27 bd Jean Moulin, 13005 Marseille, France.

E-mail addresses: blandine.courbiere@imbe.fr (B. Courbiere), virginie.tassistro@univ-amu.fr (V. Tassistro), amandine.sansoni@inserm.fr (A. Sansoni), thierry.orsiere@imbe.fr (T. Orsière), liu@cerege.fr (W. Liu), carole.di-giorgio@univ-amu.fr (C. Di Giorgio), jeanne.perrin@imbe.fr (J. Perrin).
} 
for the assessment of DNA damage in sperm and male germ cells (Baumgartner et al., 2009; Perrin et al., 2007; Preaubert et al., 2016) and in oocytes (Berthelot-Ricou et al., 2013, 2011a, 2011b; Courbiere et al., 2013; Einaudi et al., 2014). Studies using the comet assay on animal embryos are scarce and use heterogeneous protocols and species (Blerkom et al., 2001; Fabian et al., 2003; Harrouk et al., 2000; Hwang et al., 2013; Ju et al., 2010; Kitagawa et al., 2004; Müller et al., 1996; Natarajan et al., 2010; Rajesh et al., 2010; Sturmey et al., 2009; Takahashi et al., 1999, 2000; Thiyagarajan and Valivittan, 2009a, 2009b; Tranguch et al., 2003; Tsuda et al., 1998; Webster et al., 2000). As comet assay is a very sensitive test, the analysis of fresh embryos by comet assay requires the proximity between animal facilities and laboratory. Moreover, the analysis of fresh embryos does not allow control or additional analyses if required, notably after in vivo exposure or for an hypothetical use for regulatory issues.

The aim of our study was to optimize the comet assay for application on frozen mouse embryos, in order to simplify the handling and allow subsequent analysis.

\section{Material and methods}

All of the chemicals were purchased from Sigma-Aldrich (SaintQuentin Fallavier, France) unless otherwise stated.

\subsection{Institutional Review Board}

Institutional Review Board approval (C2EA-14) was obtained after submission to the National Ethics Committee on Animal Experimentation. All of the experimental protocols and animal handling procedures were approved by The National Ethics Committee on Animal Experimentation.

\subsection{Source of embryos}

In total, 1000 frozen 2-cell embryos were purchased from the ImmunoPHEnomique Center (CIPHE, Luminy, Marseille, France). Briefly, the embryos were obtained by natural mating on superovulated B6CBA females aged 5 weeks. $48 \mathrm{~h}$ after mating, the oviduct was flushed and the two-cells embryo obtained were cryopreserved. We used a slow freezing protocol with a controlled rate freezing machine and $1.5 \mathrm{M}$ propanediol as a cryoprotectant, according to the procedure described by the European Mouse Mutant Archive (EMMA) (EMMA-The European mouse mutant archive, 2013a; Hagn et al., 2007).

\subsection{Embryo thawing}

The embryos were thawed according to the procedure described by the European Mouse Mutant Archive (EMMA) (EMMA-The European mouse mutant archive, 2013b; Hagn et al., 2007). Briefly, the straw was thawed at room temperature (RT), and then the embryos were rinsed in 4 successive M2 medium drops and placed in KSOM medium (EmbryoMax $^{\circledR}$, Merck Millipore, Darmstadt, Germany).
The number of thawed embryos used for each experiment performed in this study is presented in Table 1 .

\subsection{Embryo viability and culture conditions}

To validate the use of frozen embryos instead of fresh embryos for comet assay, we assessed viability and blastulation rates in thawed embryos. After $1 \mathrm{~h}$ of recovery in KSOM, the 2-cells embryos were examined under a microscope and were classified as lysed or intact. The survival rate was defined as the ratio of the intact embryos to the total thawed embryos.

The embryos were then cultured for $24 \mathrm{~h}$ in a humidified chamber at $37{ }^{\circ} \mathrm{C}\left(95 \%\right.$ air $\left./ 5 \% \mathrm{CO}_{2}\right)$ to determine viability. The viability rate was defined by the number of 2-cell embryos moving to the 4-8 cell stage to the total intact embryos. The embryos were cultured for $24 \mathrm{~h}$ more to determine the evolution rate to the blastocyst stage, assessing the number of blastocysts compared to the total intact embryos. For each separate experiment, 20 embryos were used (5 experiments $=100$ embryos) (Table 1).

Literature review of the comet assay protocols used for mammalian embryos.

A literature review using PubMed with the key words "comet assay" and "embryo" was conducted. We excluded studies using non-mammalian species, post-implantation embryos, studies with incomplete data about the comet assay technique and studies applying the comet assay on other cells than embryos. We collected the following information from the protocols: species, embryo production, zona pellucida (ZP), embryo mixing technique in agarose, number of layers, lysis solution/duration and temperature used, incubation/electrophoresis duration, number and stage of embryos deposited per slide and technique used for the quantification of DNA damage.

The main technical details of the published protocols are presented in Table 2. We selected 14 studies using the comet assay on animal embryos matching our criteria, out of 118 studies retrieved. In these studies, fresh embryos were all obtained by natural mating (Fabian et al., 2003; Harrouk et al., 2000; Müller et al., 1996; Takahashi et al., 1999; Tranguch et al., 2003; Webster et al., 2000) or IVF (Hwang et al., 2013; Ju et al., 2010; Kitagawa et al., 2004; Natarajan et al., 2010; Rajesh et al., 2010; Sturmey et al., 2009; Takahashi et al., 2000; Thiyagarajan and Valivittan, 2009a, 2009b). This review of the literature shows that there is no standardization of the protocol: Seven different animal species were used; The ZP was removed in 4 studies; The protocols for the transfer of the embryos in the LMP agarose layer were heterogeneous: a minimum of half a blastocyst and a maximum of 20 cleavage embryos were transferred, and the volume of LMP varied from $4 \mu \mathrm{L}$ to $50 \mu \mathrm{L}$; The lysis and electrophoresis protocols were also heterogeneous. No publication described the recovery rate of the embryos in the agarose layer after lysis and electrophoresis.

The findings of this literature review were used in the following paragraphs and tests to optimize comet assay.

Table 1

Experiments performed in the study and number of thawed embryos used for each one.

\begin{tabular}{|c|c|c|c|c|}
\hline Experiments performed & Embryo stage used & Protocol used after embryo thawing & $\mathrm{Nb}$ of separate experiments & Total nb of 2-cells embryos used \\
\hline $\begin{array}{l}\text { Assessment of embryo viability and blastulation } \\
\text { rates }\end{array}$ & 2-Cell & $\begin{array}{l}\text { 2-Cells embryo in vitro culture to } \\
\text { blastocyst stage }\end{array}$ & 5 & $20 \times 5=100$ \\
\hline Impact of the nb of agarose layers on embryo & 2-Cell & CA Protocol 1 & 5 & $30 \times 5=150$ \\
\hline recovery rate & 2-Cell & CA Protocol 2 & 5 & $30 \times 5=150$ \\
\hline Impact of $\mathrm{ZP}$ on CA results & 2-Cell & CA Protocol 2 & 5 & $60 \times 5=300$ \\
\hline $\begin{array}{l}\text { Impact of genotoxic agents exposure on DNA } \\
\text { damage }\end{array}$ & 2-Cell & CA Protocol 2 & 5 & $60 \times 5=300$ \\
\hline Total & & & & 1000 \\
\hline
\end{tabular}

CA: comet assay (Protocol 1 uses 2 agarose layers; Protocol 2 uses 3 agarose layers), ZP: zona pellucida. 


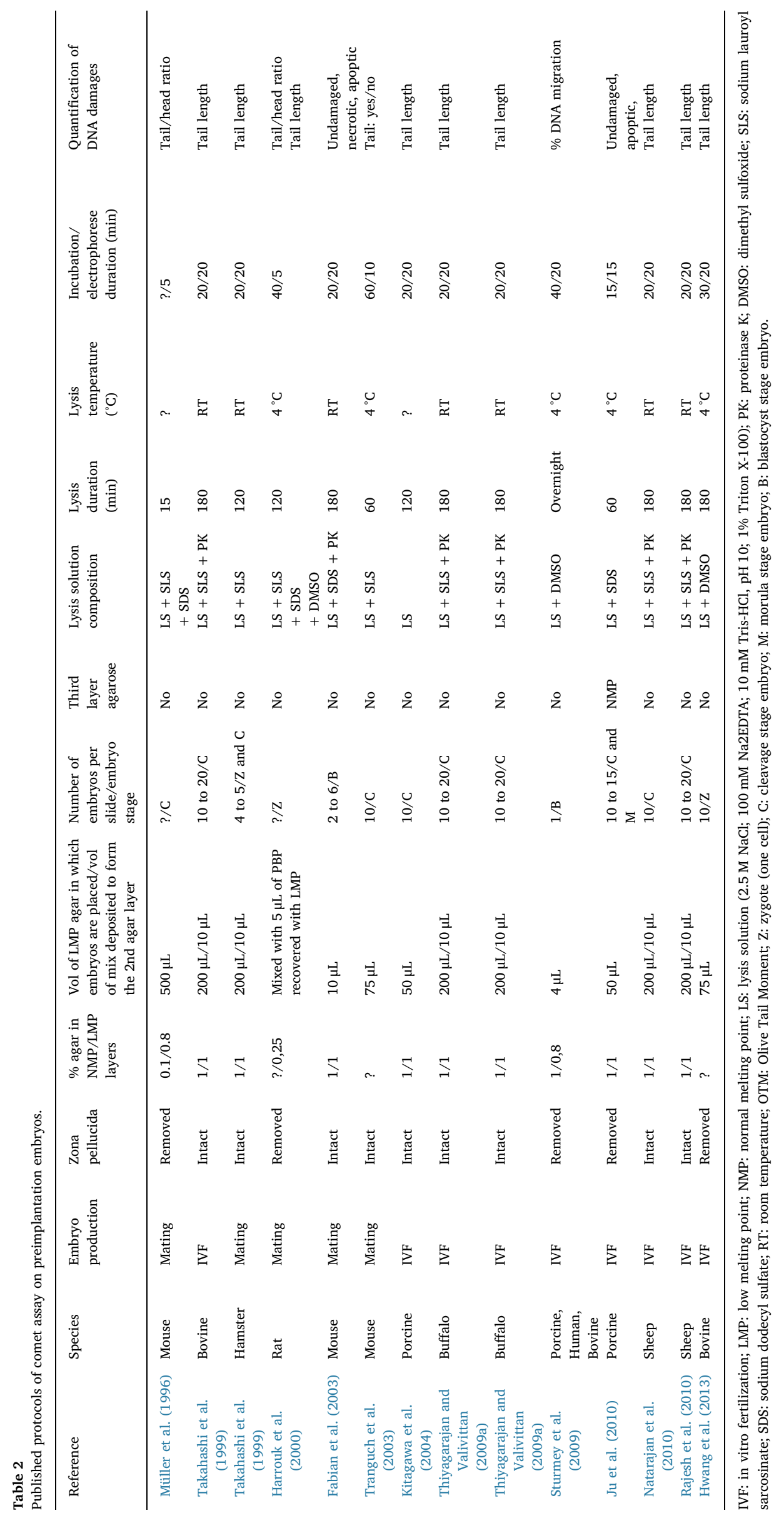




\subsection{Impact of the number of agarose layers on the embryo recovery rate}

All of the published comet assay protocols on mice embryos (Fabian et al., 2003; Harrouk et al., 2000; Hwang et al., 2013; Kitagawa et al., 2004; Müller et al., 1996; Natarajan et al., 2010; Rajesh et al., 2010; Sturmey et al., 2009; Takahashi et al., 1999, 2000; Thiyagarajan and Valivittan, 2009a, 2009b; Tranguch et al., 2003; Webster et al., 2000) used 2 layers of agarose except one (Ju et al., 2010). A glass microscope slide is initially coated with $1 \%$ high or normal-melting point (HMP, NMP) agarose (the first agarose layer), and then, the embryos are mixed with a drop of low-melting point (LMP) agarose and placed on the first layer (the second agarose layer). We compared the impact of two protocols on the rate of cell loss. In Protocol 1, as described by Berthelot-Ricou et al. (2011a) we used 2 layers. In protocol 2, we used 3 layers (as described in the "Alkaline comet assay" section). For each protocol, the recovery rate was defined by the number of embryos found and analyzed on a slide at the end of the protocol compared to the total embryos initially deposited on the slide. For each of the 5 separate experiments, 30 embryos were used with protocol 1 and 30 embryos with protocol 2 (300 embryos) (Table 1).

\subsection{Zona pellucida impact on comet assay.}

To determine the impact of the ZP on the comet assay, we tested normal embryos ( $\mathrm{ZP}+)$ and zona-free embryos (ZP - ). In the ZP- embryos, the ZP was digested by an acidic Tyrode's solution at RT and was washed three times in M2 medium before use as described by Nicolson et al. (Nicolson et al., 1975). The comet assay (Protocol 2) was performed on both control ZP + and ZP - embryos and on ZP + and ZP embryos exposed to $\mathrm{H}_{2} \mathrm{O}_{2}$. For each of the 5 separate experiments, 30 embryos were used for control (15 ZP +, $15 \mathrm{ZP}-$ ) and 30 for exposed embryos (15 ZP +, $15 \mathrm{ZP}-$ ) (300 embryos) (Table 1).

\subsection{Exposure conditions}

The subsequent experiments were performed on embryos with an intact zona pellucida ( $\mathrm{ZP}+$ ). To validate the sensitivity of the assay, we used two positive controls of well-known chemical and physical genotoxic agents (Berthelot-Ricou et al., 2011a; Kumaravel and Jha, 2006; Miranda-Vilela et al., 2010): $\mathrm{H}_{2} \mathrm{O}_{2}$ and Sun Simulated Irradiation (SSI). For the $\mathrm{H}_{2} \mathrm{O}_{2}$ group, the embryos were placed in a $220 \mu \mathrm{M} \mathrm{H}_{2} \mathrm{O}_{2}$ solution for $6 \mathrm{~min}$ at $4{ }^{\circ} \mathrm{C}$ in the dark. SSI induces DNA damage by irradiation to light. For the SSI group, light irradiation was carried out with a Suntest CPS + solar simulator (Atlas Material Testing Technology BV, Moussy le Neuf, France) equipped with a xenon arc lamp (1100 W) and special glass filters restricting transmission of light below $290 \mathrm{~nm}$ and near IR-blocking filter. The addition of glass filters limited the spectral emission to the $320-800 \mathrm{~nm}$ band (UVA-Visible light). The irradiation dose was $120 \mathrm{~kJ} / \mathrm{m}^{2}$. The temperature of the samples was kept at $4{ }^{\circ} \mathrm{C}$ by using a regulated cooling system during the irradiation experiments. For each set of experiments, the control group consisted of embryos incubated for $1 \mathrm{~h}$ in KSOM medium. For each of the 5 separate experiments, 20 embryos were analyzed for each condition (control, $\mathrm{H}_{2} \mathrm{O}_{2}$ or SSI) (300 embryos) (Table 1).

\subsection{Alkaline comet assay}

Protocol 2 for the alkaline comet assay was based on the protocol described by Berthelot-Ricou et al. (2011a) for oocytes with some modifications to adapt the method for embryos. We first covered glass microscope slides with HMP agarose (1.6\% in PBS) and then dried these slides overnight at $20^{\circ} \mathrm{C}$. A $50 \mu \mathrm{L}$ drop of $1 \%$ LMP agarose in PBS at $37^{\circ} \mathrm{C}$ was placed on the first agarose layer, and the embryos were immediately transferred from the culture medium into this drop (under a stereo microscope to visualize the embryos). The resulting suspension was then gently mixed with the $1 \%$ LMP agarose. After a few seconds of solidification, the agarose drop with the embryos was surrounded by an $80 \mu \mathrm{L}$ ring of $1 \% \mathrm{LMP}$ agarose, covered with a coverslip $(24 \times 32 \mathrm{~mm})$ and then kept $20 \mathrm{~min}$ at $4{ }^{\circ} \mathrm{C}$ for solidification (the second layer). After removing the coverslip, a third layer of $80 \mu \mathrm{L}$ of $1 \%$ LMP agarose was deposited and was covered with a coverslip $(24 \times 32 \mathrm{~mm})$ before solidification at RT. After removing the coverslips, slides were lysed in a freshly prepared lysis solution (LS) $(2.5 \mathrm{M} \mathrm{NaCl}, 100 \mathrm{mMol} \mathrm{Na2EDTA}$, 10 mMol Tris-HCl, pH 10, 1\% Triton X-100, and 10\% DMSO in ultrapure water) for $90 \mathrm{~min}$ at $4{ }^{\circ} \mathrm{C}$. DNA unwinding was performed with an alkaline solution ( $1 \mathrm{mMol} \mathrm{Na2EDTA}$ and $300 \mathrm{mMol} \mathrm{NaOH}$ ) for $20 \mathrm{~min}$ at $20{ }^{\circ} \mathrm{C}$ in a $30.5 \times 22 \mathrm{~cm}$ horizontal electrophoresis unit. Next, electrophoresis was conducted for $30 \mathrm{~min}(25 \mathrm{~V}, 300 \mathrm{~mA})$ in the same buffer solution at RT. After the electrophoretic run, the slides were neutralized 3 times with $0.4 \mathrm{M}$ Tris- $\mathrm{HCl}$ ( $\mathrm{pH} 7.5$ ), rinsed with ultrapure water, dipped into $100 \%$ methanol (HPLC grade purity solvent), and dried overnight at RT. Staining was performed with a propidium iodide solution $(0.1 \mathrm{mg} / \mathrm{mL})$, and the slides were examined with a fluorescence microscope at a $400 \times$ final magnification (Carl ZEISS Axio Imager A2, Bayern, Germany). The digital pictures were analyzed, and the determination of the \% tail DNA was performed with a CCD Nikon camera (DS-Fi2, Nikon, Champigny-sur Marne, France) and Komet software (version 7.0, Nottingham, UK).

\subsection{Statistical analysis}

The \% tail DNA was used to determine the DNA damage in each embryo. The experiments were replicated 5 times for each group. A $t$ test or Pearson's Chi-squared test as appropriate for statistical analysis was performed using StatView software. The \% tail DNA is expressed as the means \pm standard error of the mean (S.E.M.). A probability of $p<0.05$ was considered significant.

\section{Results}

\subsection{Embryo survival and culture}

After thawing and recovery in $\mathrm{KSOM}$, the overall survival rate of the 5 separate experiments was 85\% (85/100: 85 intact embryos and 15 lysed embryos). After a $24 \mathrm{~h}$ culture, the viability rate was $99 \%$ (84 2cell embryos moving to the 4-8 cell stage out of 85 intact embryos). After a $48 \mathrm{~h}$ culture, the blastocyst rate was $82 \%$ (70 blastocysts obtained from in vitro culture of 85 intact 2-cell embryos).

\subsection{Impact of the number of agarose layers on the embryos recovery rate}

The overall recovery rate in the 5 different experiments using Protocol 1 (two agarose layers) was 3,3\% $(n=5 / 150)$. With Protocol 2 (three agarose layers), the overall recovery rate was significantly increased to $71,3 \%(n=107 / 150)(p<0.0001)$.

\subsection{Impact of the zona pellucida on the comet assay}

The impact of the ZP on the Comet Assay is illustrated in Fig. 1. No statistically significant difference was observed in DNA damage for the $\mathrm{ZP}-$ and $\mathrm{ZP}+$ control groups $(12.60 \pm 2.53 \%$ tail DNA vs $11.04 \pm 1.50, p=0.5837$, respectively). The $\mathrm{ZP}-$ and $\mathrm{ZP}+$ groups after $\mathrm{H}_{2} \mathrm{O}_{2}$ exposure were also not statistically significant different $(49.23 \pm 4.16 \%$ Tail DNA vs $41.13 \pm 4.31, p=0.1820$, respectively).

\subsection{Alkaline comet assay}

Fig. 2 shows the aspects of the comets observed in the control groups (A) and in the groups exposed to the genotoxic agents (B, C). The control embryos showed a low basal level of DNA damage. Fig. 3 shows that $\mathrm{H}_{2} \mathrm{O}_{2}$ and SSI induced a statistically significant increase in 


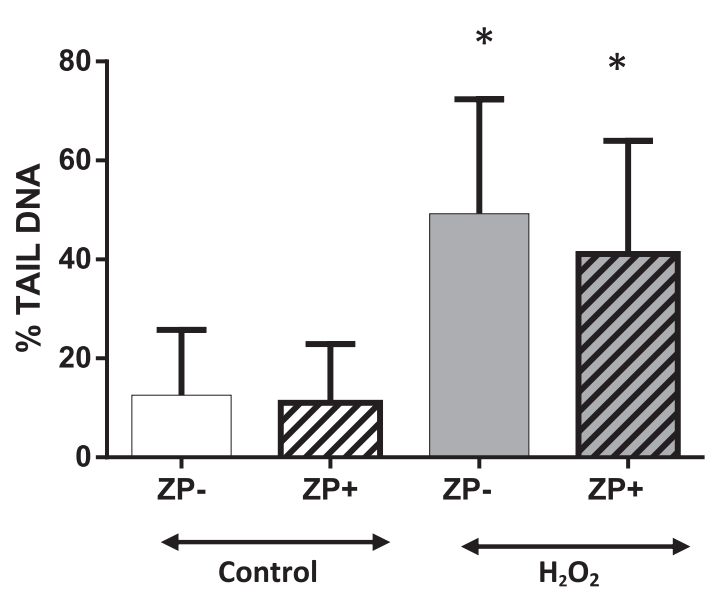

Fig. 1. No impact of zona pellucida for 2-cell embryo comet assay. ZP - : zona-free embryo; $\mathrm{ZP}+$ : intact embryo; $\mathrm{H}_{2} \mathrm{O}_{2}$ : exposure to hydrogen peroxide $\left(220 \mu \mathrm{M} \mathrm{H} \mathrm{H}_{2} \mathrm{O}_{2}\right)$. No statistical difference was observed on DNA damage between $\mathrm{ZP}$ - et $\mathrm{ZP}+$ embryo on control group and on $\mathrm{H}_{2} \mathrm{O}_{2}$ exposure group. *: $p<0.01$ between DNA damage in Control and in $\mathrm{H}_{2} \mathrm{O}_{2}$ exposed embryos. $t$-Test.

DNA damage compared with the control group $(41.13 \pm 4.31 \%$ Tail DNA, $36.33 \pm 3.02$ and $11.04 \pm 1.50, p<0.0001$, respectively).

\section{Discussion}

\subsection{Thawed embryos can be used for comet assay}

We describe, for the first time, the use of the alkaline comet assay on thawed mouse embryos by optimizing protocols that were previously published in the literature. Control mouse thawed embryos showed a low basal level of DNA damage, comparable to the level of DNA damage observed in control sperm (Preaubert et al., 2016) and control oocytes (Berthelot-Ricou et al., 2011a) in our hands. In the literature, we selected 14 studies using the comet assay on mammal embryos matching with our criteria, and no study was performed on frozen embryos. Among the 3 studies in mice (Fabian et al., 2003; Müller et al., 1996; Tranguch et al., 2003), only Fabian et al. evaluated the evolution rate to the blastocyst stage in embryos obtained by natural fertilization, and it was estimated to be $88 \%$. This result suggests that the freezing/thawing step in our protocol did not affect the embryo quality. The use of frozen embryos simplifies the handling by allowing the researcher to dissociate the location and the timing of the embryo collection from the embryo analysis, which facilitates collaboration between laboratories. The use of frozen embryos also allows subsequent analysis if required.

Deleting the removal of zona pellucida improves feasibility.

Many authors remove the ZP before the comet assay, in order to study individual blastomeres and to allow DNA migration (Harrouk et al., 2000; Hwang et al., 2013; Ju et al., 2010; Müller et al., 1996; Sturmey et al., 2009; Webster et al., 2000); nevertheless, they did not study the impact the ZP on the downstream results. Moreover, this step requires the use of a chemical and physical stress that could unnecessarily damage the embryo and induce DNA damage. In a previous study of our group (Berthelot-Ricou et al., 2011a), we performed the

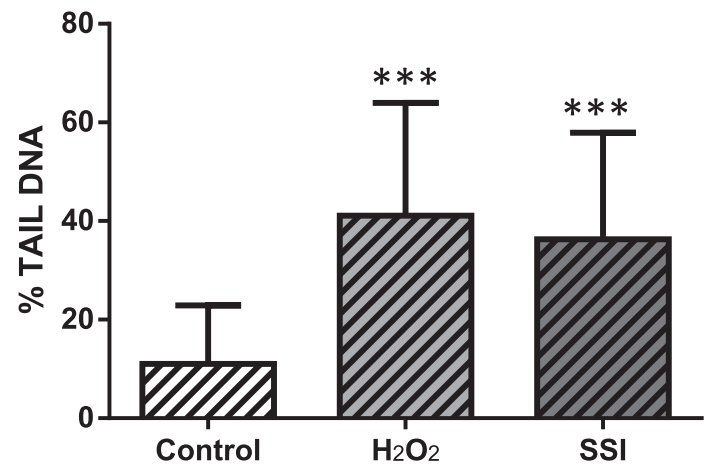

Fig. 3. \% Tail DNA of mouse 2-cells embryo with zona pellucida exposed to two genotoxic agents and measured by comet assay. Control; $\mathrm{H}_{2} \mathrm{O}_{2}$, exposure to hydrogen peroxide $(220 \mu \mathrm{M})$; SSI, exposure to simulated sunlight irradiation $\left(120 \mathrm{~J} / \mathrm{cm}^{2}\right)$; ***statistical significance $(p<0.001)$. $t$-Test.

comet assay on mouse oocytes with and without ZP, and no significant difference was found in the DNA damage in both of the groups. In the present study, we did not observe significant differences in DNA damage in the ZP- and ZP + embryos, indicating that the presence of the ZP did not affect the embryo lysis and/or DNA migration. Deleting the ZP removal step simplifies the protocol, saving time and improving feasibility.

\subsection{Adding a third layer of agarose decreases the embryo loss}

One of the main issues of our study was to reduce embryo loss during lysis and electrophoresis. As the main difficulty of embryos studies is the low number of available samples, this issue was very important. The significant embryo loss we experienced with Protocol 1 (two agarose layers) was surprising. Indeed, we never observed such a significant loss during the comet assay with Protocol 1 on mouse oocytes (Berthelot-Ricou et al., 2011b, 2011a, 2013; Courbiere et al., 2013; Einaudi et al., 2014; Greco et al., 2015), which sizes are comparable to the embryo size. In the studies using the comet assay on embryos, selected by our literature review, the authors used protocols with 2 agarose layers and deposited between 1 and 20 embryos per glass slide (Table 2), which is comparable with Protocol 1 (20 embryos, 2 agarose layers). None of these studies described the ratio between the number of embryos deposited and the number of recovered embryos after lysis and electrophoresis. Nevertheless, we can assume that embryo loss was not as high as in the present study. Our hypothesis is that the important embryo loss we observed with Protocol 1 could be related to the alteration of ZP due to the freezing-thawing protocol: dehydratation due to cryprotectant could induce hardening and thinning of the ZP (Cavusoglu et al., 2016; Trounson and Mohr, 1983). These alterations could modify the interaction between the ZP and the agarose, and increase the embryo loss during the steps of coverslip removal and/ or lysis. The use of a third agarose layer dramatically decreased the rate of embryo loss.
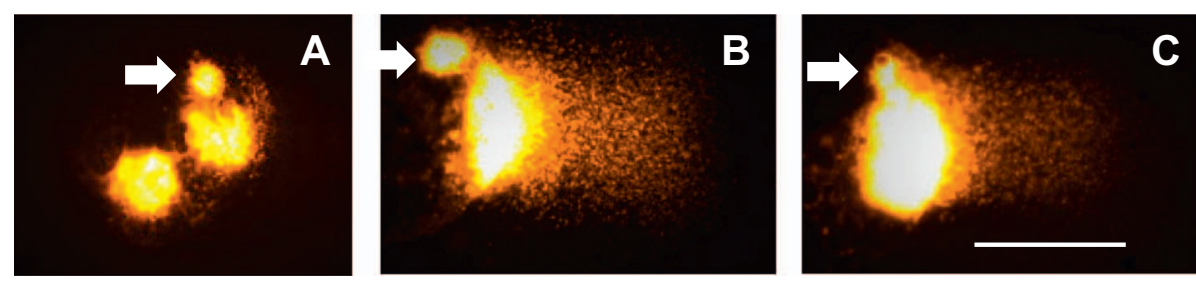

Fig. 2. Examples of different aspects of DNA damage as detected by the comet assay on mouse 2-cell embryos with zona pellucida. A: Control group: intact 2-cell embryo after comet assay process. B: 2-cell embryo exposed in vitro for 5 min to $220 \mu \mathrm{Mol} \mathrm{H}_{2} \mathrm{O}_{2}$. C: 2-Cell embryo exposed in vitro to Simulated Sun Irradiation. The direction of electrophoresis was from left to right, and the comet tail containing the DNA fragments was stained by iodide propidium $0.1 \mathrm{mg} / \mathrm{mL}$. When 2-cell embryo DNA is intact, the two nuclei remain separated (A). When 2-cell embryo DNA is damaged, the two nuclei overlap and appear merged. (B, C). Arrows show the polar bodies. Scale bar, $100 \mu \mathrm{m}$. Magnification $\times 400$. 


\subsection{Limitations}

In our study, we measured DNA damage by the \% Tail DNA, as recently recommended by the OECD (OECD, 2014). The use of the \% Tail DNA gives a clear indication of the appearance of the comets, and it is also linearly related to the DNA break frequency over a wide range of levels of damage (Ersson and Möller, 2011; Hartmann et al., 2003; OECD, 2014; Uno et al., 2015). Therefore, the amount of DNA damage we observed could not be easily compared with the DNA damage in the other studies we selected. Indeed, the tail moment and/or the tail length measurements are also reported herein (Table 2), as these studies were published before the OECD recommendations. To better evaluate the sensitivity of our optimized protocol, despite the inability to compare these factors, we used two well-known genotoxic agents as positive controls. Nevertheless, \% Tail DNA should be used for DNA damage quantification. Another limitation is that we performed the Comet Assay experiments on thawed embryos after an in vitro exposure to two well-known genotoxic agents; our protocol should also be tested to detect embryo DNA damage induced after in vivo mice exposure associated to DNA damage in gametes (Einaudi et al., 2014; Singh et al., 2015).

\section{Conclusion}

Our optimized protocol of the comet assay on thawed embryos allows the rapid detection of primary DNA damage in the mouse embryo. We simplified the protocol by showing that the lack of ZP removal does not alter DNA lysis and migration. In addition, we demonstrated that the adjunction of a third agarose layer decreases embryo loss and allows for the study of a small amount of embryos. This new optimized tool could be used to analyze DNA damage in mice embryos after in vivo exposure of the mothers to environmental agents.

\section{Funding}

This work was conducted thanks to the support of the A*MIDEX project "CREER" (n ANR-11-IDEX-0001-02), which was funded by the "Investissements d'Avenir" French Government program and managed by the French National Research Agency (ANR). The study received additional funding from "Association Laurette Fugain" (no. 2014/01), the ARC Foundation (no. PJA 20141201596), and the Aix Marseille University Foundation (no. 16/07/01).

\section{Conflicts of interest}

None declared.

\section{Acknowledgments}

The authors thank technicians from CECOS Laboratory (AP-HM La Conception) for technical help.

\section{References}

Baumgartner, A., Cemeli, E., Anderson, D., 2009. The comet assay in male reproductive toxicology. Cell Biol. Toxicol. 25, 81-98.

Berthelot-Ricou, A., Perrin, J., Di Giorgio, C., De Meo, M., Botta, A., Courbiere, B., 2011a. Comet assay on mouse oocytes: an improved technique to evaluate genotoxic risk on female germ cells. Fertil. Steril. 95, 1452-1457.

Berthelot-Ricou, A., Perrin, J., di Giorgio, C., de Meo, M., Botta, A., Courbiere, B., 2011 b. Assessment of 1,2-propanediol (PrOH) genotoxicity on mouse oocytes by comet assay. Fertil. Steril. 96, 1002-1007.
Berthelot-Ricou, A., Perrin, J., di Giorgio, C., de Meo, M., Botta, A., Courbiere, B., 2013. Genotoxicity assessment of mouse oocytes by comet assay before vitrification and after warming with three vitrification protocols. Fertil. Steril. 100, 882-888.

Blerkom, J.V., Davis, P., Alexander, S., 2001. A microscopic and biochemical study of fragmentation phenotypes in stage-appropriate human embryos. Hum. Reprod. 16, 719-729.

Bujan, L., Walschaerts, M., Brugnon, F., Daudin, M., Berthaut, I., Auger, J., Saias, J., Szerman, E., Moinard, N., Rives, N., Hennebicq, S., 2014. Impact of lymphoma treatments on spermatogenesis and sperm deoxyribonucleic acid: a multicenter prospective study from the CECOS network. Fertil. Steril. 102, 667-674.e3.

Cavusoglu, T., Popken, J., Guengoer, T., Yilmaz, O., Uyanikgil, Y., Ates, U., Baka, M., Oztas, E., Zakhartchenko, V., 2016. Ultra-structural alterations in in vitro produced four-cell bovine embryos following controlled slow freezing or vitrification. Anat. Histol. Embryol. 45, 291-307.

Courbiere, B., Auffan, M., Rollais, R., Tassistro, V., Bonnefoy, A., Botta, A., Rose, J., Orsière, T., Perrin, J., 2013. Ultrastructural interactions and genotoxicity assay of cerium dioxide nanoparticles on mouse oocytes. Int. J. Mol. Sci. 14, 21613-21628.

Einaudi, L., Courbiere, B., Tassistro, V., Prevot, C., Sari-Minodier, I., Orsiere, T., Perrin, J., 2014. In vivo exposure to benzo(a)pyrene induces significant DNA damage in mouse oocytes and cumulus cells. Hum. Reprod. 29, 548-554.

EMMA-The European mouse mutant archive, 2013a. Harvest and Cryopreservation of In Vivo Derived Mouse Embryos.

EMMA-The European mouse mutant archive, 2013b. Thawing and Use of Cryopreserved Mouse Embryos.

Ersson, C., Möller, L., 2011. The effects on DNA migration of altering parameters in the comet assay protocol such as agarose density, electrophoresis conditions and durations of the enzyme or the alkaline treatments. Mutagenesis 26, 689-695.

Esquerré-Lamare, C., Isus, F., Moinard, N., Bujan, L., 2015. Sperm DNA fragmentation after radioiodine treatment for differentiated thyroid cancer. Basic Clin. Androl. 25,8 .

Fabian, D., Rehák, P., Czikková, S., Il'ková, G., Baran, V., Koppel, J., 2003. Induced cell death of preimplantation mouse embryos cultured in vitro evaluated by comet assay. Theriogenology 60, 691-706.

Goldstone, A.E., Chen, Z., Perry, M.J., Kannan, K., Louis, G.M.B., 2015. Urinary bisphenol A and semen quality, the LIFE study. Reprod. Toxicol. Elmsford N 51, 7-13.

Greco, F., Perrin, J., Auffan, M., Tassistro, V., Orsière, T., Courbiere, B., 2015. A new approach for the oocyte genotoxicity assay: adaptation of comet assay on mouse cumulus-oocyte complexes. Lab. Anim. 49, 251-254.

Hagn, M., Marschall, S., de Angelis, M.H., 2007. EMMA-the European mouse mutant archive. Brief. Funct. Genomic. Proteomic. 6, 186-192.

Harrouk, W., Codrington, A., Vinson, R., Robaire, B., Hales, B.F., 2000. Paternal exposure to cyclophosphamide induces DNA damage and alters the expression of DNA repair genes in the rat preimplantation embryo. Mutat. Res. Repair 461, 229-241.

Hartmann, A., Agurell, E., Beevers, C., Brendler-Schwaab, S., Burlinson, B., Clay, P., Collins, A., Smith, A., Speit, G., Thybaud, V., Tice, R.R., 4th International Comet Assay Workshop, 2003. Recommendations for conducting the in vivo alkaline Comet assay. 4th International Comet Assay Workshop. Mutagenesis 18, 45-51.

Horváthová, E., Dusinská, M., Shaposhnikov, S., Collins, A.R., 2004. DNA damage and repair measured in different genomic regions using the comet assay with fluorescent in situ hybridization. Mutagenesis 19, 269-276.

Hwang, I.-S., Bae, H.-K., Cheong, H.-T., 2013. Mitochondrial and DNA damage in bovine somatic cell nuclear transfer embryos. J. Vet. Sci. 14, 235-240.

Ju, S., Rui, R., Lu, Q., Lin, P., Guo, H., 2010. Analysis of apoptosis and methyltransferase mRNA expression in porcine cloned embryos cultured in vitro. J. Assist. Reprod. Genet. 27, 49-59.

Kitagawa, Y., Suzuki, K., Yoneda, A., Watanabe, T., 2004. Effects of oxygen concentration and antioxidants on the in vitro developmental ability, production of reactive oxygen species (ROS), and DNA fragmentation in porcine embryos. Theriogenology 62, 1186-1197.

Kolstad, H.A., Bonde, J.P., Spano, M., Giwercman, A., Zschiesche, W., Kaae, D., Larsen, S.B., Roeleveld, N., 1999. Change in semen quality and sperm chromatin structure following occupational styrene exposure. ASCLEPIOS. Int. Arch. Occup. Environ. Health $72,135-141$.

Kumaravel, T.S., Jha, A.N., 2006. Reliable Comet assay measurements for detecting DNA damage induced by ionising radiation and chemicals. Mutat. Res. Toxicol. Environ. Mutagen. 605, 7-16.

Ménézo, Y., Dale, B., Cohen, M., 2010. DNA damage and repair in human oocytes and embryos: a review. Zygote Camb. Engl. 18, 357-365.

Miranda-Vilela, A.L., Alves, P.C., Akimoto, A.K., Lordelo, G.S., Gonçalves, C.A., Grisolia, C.K., Klautau-Guimarães, M.N., 2010. Gene polymorphisms against DNA damage induced by hydrogen peroxide in leukocytes of healthy humans through comet assay: a quasi-experimental study. Environ. Health Glob. Access Sci. Source 9, 21.

Müller, W.-ü, Bauch, T., Wojcik, A., Böcker, W., Streffer, C., 1996. Comet assay studies indicate that caffeine-mediated increase in radiation risk of embryos is due to inhibition of DNA repair. Mutagenesis 11, 57-60.

Natarajan, R., Shankar, M.B., Munuswamy, D., 2010. Effect of $\alpha$-tocopherol supplementation on in vitro maturation of sheep oocytes and in vitro development of preimplantation sheep embryos to the blastocyst stage. J. Assist. Reprod. Genet. 27, 483-490.

Nicolson, G.L., Yanagimachi, R., Yanagimachi, H., 1975. Ultrastructural localization of lectin-binding sites on the zonae pellucidae and plasma membranes of mammalian eggs. J. Cell Biol. 66, 263-274.

OECD, 2014. Test No. 489: In Vivo Mammalian Alkaline Comet Assay. Organisation for Economic Co-operation and Development, Paris.

Pecou, S., Moinard, N., Walschaerts, M., Pasquier, C., Daudin, M., Bujan, L., 2009. Ribavirin and pegylated interferon treatment for hepatitis $\mathrm{C}$ was associated not only 
with semen alterations but also with sperm deoxyribonucleic acid fragmentation in humans. Fertil. Steril. 91 (933.e17-22).

Perrin, J., Lussato, D., De Méo, M., Durand, P., Grillo, J.-M., Guichaoua, M.-R., Botta, A., Bergé-Lefranc, J.-L., 2007. Evolution of DNA strand-breaks in cultured spermatocytes: the comet assay reveals differences in normal and $\gamma$-irradiated germ cells. Toxicol. in Vitro 21, 81-89.

Perrin, J., Tassistro, V., Mandon, M., Grillo, J.-M., Botta, A., Sari-Minodier, I., 2011. Tobacco consumption and benzo(a)pyrene-diol-epoxide-DNA adducts in spermatozoa: in smokers, swim-up procedure selects spermatozoa with decreased DNA damage. Fertil. Steril. 95, 2013-2017.

Preaubert, L., Courbiere, B., Achard, V., Tassistro, V., Greco, F., Orsiere, T., Bottero, J.-Y., Rose, J., Auffan, M., Perrin, J., 2016. Cerium dioxide nanoparticles affect in vitro fertilization in mice. Nanotoxicology 10, 111-117.

Rajesh, N., Shankar, M.B., Deecaraman, M., 2010. Effect of vitamin A supplementation at different gaseous environments on in vitro development of pre-implantation sheep embryos to the blastocyst stage. Animal 4, 1884-1890.

Roti Roti, E.C., Leisman, S.K., Abbott, D.H., Salih, S.M., 2012. Acute doxorubicin insult in the mouse ovary is cell- and follicle-type dependent. PLoS One 7, e42293.

Simon, L., Murphy, K., Shamsi, M.B., Liu, L., Emery, B., Aston, K.I., Hotaling, J., Carrell, D.T., 2014. Paternal influence of sperm DNA integrity on early embryonic development. Hum. Reprod. Oxf. Engl. 29, 2402-2412.

Singh, S., Giri, A., Giri, S., 2015. The antimalarial agent artesunate causes sperm DNA damage and hepatic antioxidant defense in mice. Mutat. Res. Toxicol. Environ. Mutagen. 777, 1-6.

Speit, G., Vasquez, M., Hartmann, A., 2009. The comet assay as an indicator test for germ cell genotoxicity. Mutat. Res. 681, 3-12.

Sturmey, R.G., Hawkhead, J.A., Barker, E.A., Leese, H.J., 2009. DNA damage and metabolic activity in the preimplantation embryo. Hum. Reprod. 24, 81-91. http://dx. doi.org/10.1093/humrep/den346.

Takahashi, M., Saka, N., Takahashi, H., Kanai, Y., Schultz, R.M., Okano, A., 1999. Assessment of DNA damage in individual hamster embryos by comet assay. Mol. Reprod. Dev. 54, 1-7.

Takahashi, M., Keicho, K., Takahashi, H., Ogawa, H., Schulte, R.M., Okano, A., 2000 Effect of oxidative stress on development and DNA damage in in-vitro cultured bovine embryos by comet assay. Theriogenology 54, 137-145.
Thiyagarajan, B., Valivittan, K., 2009a. Effect of all-trans retinol on in vitro development of preimplantation buffalo embryos. Animal 3, 385.

Thiyagarajan, B., Valivittan, K., 2009b. Ameliorating effect of vitamin E on in vitro development of preimplantation buffalo embryos. J. Assist. Reprod. Genet. 26, $217-225$.

Thompson, J., Bannigan, J., 2008. Cadmium: toxic effects on the reproductive system and the embryo. Reprod. Toxicol. Elmsford N 25, 304-315.

Tranguch, S., Steuerwald, N., Huet-Hudson, Y.M., 2003. Nitric oxide synthase production and nitric oxide regulation of preimplantation embryo development. Biol. Reprod. $68,1538-1544$.

Trounson, A., Mohr, L., 1983. Human pregnancy following cryopreservation, thawing and transfer of an eight-cell embryo. Nature 305, 707-709.

Tsuda, S., Kosaka, Y., Matsusaka, N., Sasaki, Y.F., 1998. Detection of pyrimethamineinduced DNA damage in mouse embryo and maternal organs by the modified alkaline single cell gel electrophoresis assay. Mutat. Res. Toxicol. Environ. Mutagen. 415, 69-77.

Uno, Y., Kojima, H., Omori, T., Corvi, R., Honma, M., Schechtman, L.M., Tice, R.R., Burlinson, B., Escobar, P.A., Kraynak, A.R., Nakagawa, Y., Nakajima, M., Pant, K. Asano, N., Lovell, D., Morita, T., Ohno, Y., Hayashi, M., 2015. JaCVAM-organized international validation study of the in vivo rodent alkaline comet assay for the detection of genotoxic carcinogens: I. Summary of pre-validation study results. Mutat. Res. Genet. Toxicol. Environ. Mutagen. 786-788, 3-13.

Webster, W.S., Vaghef, H., Ryan, B., Dencker, L., Hellman, B., 2000. Measurement of DNA damage by the comet assay in rat embryos grown in media containing high concentrations of vitamin K1. Toxicol. in Vitro 14, 95-99.

Zenzes, M.T., Bielecki, R., Reed, T.E., 1999. Detection of benzo(a)pyrene diol epoxideDNA adducts in sperm of men exposed to cigarette smoke. Fertil. Steril. 72, 330-335.

Zhao, J., Zhang, Q., Wang, Y., Li, Y., 2014. Whether sperm deoxyribonucleic acid fragmentation has an effect on pregnancy and miscarriage after in vitro fertilization/ intracytoplasmic sperm injection: a systematic review and meta-analysis. Fertil. Steril. 102, 998-1005.e8.

Zhou, Y., Fu, X.-M., He, D.-L., Zou, X.-M., Wu, C.-Q., Guo, W.-Z., Feng, W., 2016. Evaluation of urinary metal concentrations and sperm DNA damage in infertile men from an infertility clinic. Environ. Toxicol. Pharmacol. 45, 68-73. 